\title{
PENYISIHAN POLUTAN DARI AIR LINDI TEMPAT PEMBUANGAN SAMPAH DENGAN METODE PRESIPITASI STRUVITE: PENGARUH DOSIS PRESIPITAN DAN pH
}

\section{REMOVAL OF POLLUTANTS FROM LEACHATE FROM MUNICIPAL SOLIDS WASTES LANDFILL USING PRECIPITATION METHOD: THE EFFECTS OF PRECIPITANT DOSE AND pH}

\author{
Suprihatin*), Mohammad Yani, dan Dewi Ratnasari \\ Departemen Teknologi Industri Pertanian, Fakultas Teknologi Pertanian, Institut Pertanian Bogor \\ Kampus IPB Darmaga, PO Box 220 Bogor 16002, Indonesia \\ E-mail : suprihatin167@gmail.com
}

Makalah: Diterima 27 November 2018; Diperbaiki 12 Juni 2019; Disetujui 30 Juni 2019

\begin{abstract}
Leachate is a waste water formed from the disposed garbage in landfill site. Leachate has a high content of ammonium that can contaminate water. Ammonium removal can be done by struvite precipitation. Struvite precipitation is a process of precipitation by chemical reactions assisted with precipitant chemicals containing $\mathrm{Mg}^{2+}$ and $\mathrm{PO}_{4}{ }^{3-}$ forming a precipitate of struvite crystals $\left(\mathrm{MgNH}_{4} \mathrm{PO}_{4} \cdot 6 \mathrm{H}_{2} \mathrm{O}\right)$. This study aimed to determine the effect of molar ratio and $\mathrm{pH}$ on ammonium removal and other important pollutants from leachate. The leachate used for the experiments was taken from landfill Galuga, Bogor Regency that is used for disposal of municipal solid wastes from Bogor City and its surroundings. $\mathrm{MgCl}_{2} .6 \mathrm{H}_{2} \mathrm{O}$ and $\mathrm{Na}_{2} \mathrm{HPO}_{4} .2 \mathrm{H}_{2} \mathrm{O}$ were used as precipitants. The process was conducted in a jar test with stirring speed of $120 \mathrm{rpm}$ for 15 minutes with sedimentation time of 45 minutes. Results showed that this process could reduce ammonium concentration as well as other important pollutant levels, such as COD, TSS, turbidity, and colour. The best ammonium removal efficiency was obtained at molar ratio of 1: 1.3: 1.2 and $\mathrm{pH} 9$ with an ammonium removal of $80.51 \%$. In this condition, removals of $46.67 \%$ COD, TSS $96.04 \%$, turbidity $86.1 \%$, and colour of $86.43 \%$ were achieved.
\end{abstract}

Keywords: Ammonium, leachate, molar ratio, precipitation, struvite

\section{ABSTRAK}

Air lindi merupakan air yang terbentuk dari timbunan sampah. Air lindi memiliki kandungan amonium dan polutan organik lainnya yang cukup tinggi yang dapat mencemari air. Penurunan kadar amonium dapat dilakukan dengan cara presipitasi struvite. Presipitasi struvite merupakan proses pengendapan melalui reaksi kimia dengan bantuan bahan kimia presipitan yang mengandung $\mathrm{Mg}^{2+}$ dan $\mathrm{PO}_{4}{ }^{3-}$ sehingga terbentuk endapan berupa kristal struvite $\left(\mathrm{MgNH}_{4} \mathrm{PO}_{4} \cdot 6 \mathrm{H}_{2} \mathrm{O}\right)$. Penelitian ini bertujuan mengetahui pengaruh rasio molar dan $\mathrm{pH}$ pada penyisihan amonium dan polutan penting lainnya dari air lindi. Air lindi yang digunakan untuk percobaan diambil dari tempat pembuangan sampah domestik Galuga, Kabupaten Bogor. Presipitan yang digunakana dalah $\mathrm{MgCl}_{2} .6 \mathrm{H}_{2} \mathrm{O}$ dan $\mathrm{Na}_{2} \mathrm{HPO}_{4} \cdot 2 \mathrm{H}_{2} \mathrm{O}$. Proses pengadukan menggunakan jar test dengan kecepatan pengadukan 120 rpm selama 15 menit dan pengendapan selama 45 menit. Hasil penelitian menunjukkan bahwa proses ini dapat menurunkan selain kadar amonium juga kadar polutan penting lainnya, seperti COD, TSS, kekeruhan dan warna. Efisiensi penurunan amonium terbaik diperoleh pada rasio molar 1:1,3:1,2 dan $\mathrm{pH} 9$ dengan efisiensi sebesar $80,51 \%$. Pada kondisi ini, penyisihan COD sebesar 46,67\%, TSS 96,04\%, kekeruhan $86,1 \%$, dan warna sebesar $86,43 \%$.

Kata kunci: air lindi, amonium, presipitasi, struvite

\section{PENDAHULUAN}

Air lindi dari tempat pembuangan sampah (TPA) merupakan air limbah yang sangat tercemar dan kompleks. Komposisi air lindi ditentukan oleh proses biologis, kimia, dan fisik dan rezim aliran air di tempat pembuangan sampah tersebut (Stegmann at al., 2005). Selain itu, konsentrasi bahan polutan dan volume air lindi dari TPA dipengaruhi oleh jenis dan komposisi sampah, kondisi iklim, serta kondisi tempat pembuangan akhir tersebut. Air lindi dari tempat pembuangan sampah umumnya memiliki kandungan bahan organik (COD dan $\mathrm{BOD}_{5}$ ) dan amonium yang tinggi, logam serta berbagai jenis garam anorganik lainnya (Kochany dan Kochany, 2009). Karena kandungannya tersebut, air lindi berpotensi mencemari air permukaan atau air tanah, jika dibuang langsung ke lingkungan tanpa mengalami penanganan yang memadai.

Pengolahan air lindi dapat dilakukan dengan berbagai metode pengolahan, baik proses fisik, kimia, maupun biologis (Chou et al., 2013). Proses pengolahan secara fisik-kimia menghasilkan tingkat penurunan polutan yang cukup baik, tetapi metode ini membutuhkan biaya yang tinggi seperti biaya penyediaan alat, serta biaya energi dan bahan kimia, sehingga membutuhkan perancangan proses yang tepat untuk meminimumkan penggunaan energi 
dan bahan kimia tersebut. Proses biologis umumnya memerlukan biaya yang relatif murah, karena tidak atau hanya sedikit membutuhkan bahan kimia tambahan. Akan tetapi proses biologis umumnya berlangsung relatif lama karena air lindi mengandung bahan-bahan yang sulit terdegradasi secara biologis, bahkan sering mengandung komponen bersifat toksik terhadap mikroorganisme (Anglada et al., 2011). Oleh karena itu, pembuangan air lindi masih dapat menyebabkan masalah polusi, seperti eutrofikasi ke badan air. Solusi yang layak untuk masalah yang dihasilkan adalah penggunaan proses fisik-kimia untuk menghilangkan nitrogen amonia dari air lindi (leachate) sebelum diolah dengan metode pengolahan biologis (Huang et al., 2014).

Salah satu metode fisik-kimia yang dapat digunakan untuk menurunkan kadar amonium dan fosfat dalam air lindi adalah presipitasi struvite. Proses presipitasi ini merupakan salah satu metode pengolahan limbah cair dengan cara kimiawi. Pada rinsipnya proses presipitasi struvite merupakan proses pengendapan melalui reaksi kimia dengan bantuan bahan kimia presipitan yang mengandung $\mathrm{Mg}^{2+}$ dan $\mathrm{PO}_{4}{ }^{3-}$. Reaksi amonium dengan $\mathrm{Mg}^{2+}$ dan $\mathrm{PO}_{4}{ }^{3-}$ membentuk endapan berupa kristal struvite $\left(\mathrm{MgNH}_{4} \mathrm{PO}_{4} \cdot 6 \mathrm{H}_{2} \mathrm{O}\right)$. Reaksi pembentukan struvite adalah sebagai berikut (Zhang et al., 2009; Turker dan Elen, 2010):

$$
\mathrm{Mg}^{2+}+\mathrm{NH}_{4}{ }^{+}+\mathrm{PO}_{4}{ }^{3-}+\mathrm{H}_{2} \mathrm{O} \leftrightarrow \mathrm{MgNH}_{4} \mathrm{PO}_{4} \cdot 6 \mathrm{H}_{2} \mathrm{O}
$$

Telah terbukti bahwa struvite dapat menjadi sumber $\mathrm{N}, \mathrm{Mg}^{+2}$, dan fosfor (P) yang sangat efektif untuk tanaman dan dapat digunakan sebagai pupuk lepas lambat pada tingkat aplikasi yang tinggi tanpa merusak akar tanaman (Turker dan Elen, 2010). Garam $\mathrm{NaCl}$ yang terbentuk hanya sedikit dan memiliki kelarutan yang tinggi sehingga tidak berpengaruh terhadap pembentukan endapan maupun proses penyisihan konsentrasi $\mathrm{NH}_{4}{ }^{+}$. Durasi pengadukan dipilih selama 15 menit karena berdasarkan penelitian Kim et al. (2009), pengadukan yang berlebih akan mengakibatkan terlepasnya senyawa $\mathrm{PO}_{4}{ }^{3-}$ dari endapan struvite. Data termodinamika dari literatur (Turker dan Elen, 2010) menunjukkan bahwa sejumlah senyawa $\mathrm{Mg}^{2+}$ dapat mengendap dari larutan yang mengandung, ion $\mathrm{NH}_{4}{ }^{+}$dan $\mathrm{PO}_{4}{ }^{3-}$, magnesium hydrogen phosphate trihydrate atau newberyite $\left(\mathrm{MgHPO}_{4} 3 \mathrm{H}_{2} \mathrm{O}\right)$ dan trimagnesium fosfat dalam 2 keadaan hidrasi, $\mathrm{Mg}_{3}\left(\mathrm{PO}_{4}\right)_{2} .22 \mathrm{H}_{2} \mathrm{O}$ dan $\mathrm{Mg}_{3}\left(\mathrm{PO}_{4}\right)_{2} .8 \mathrm{H}_{2} \mathrm{O}$ (bobierrite).

Proses presipitasi ini dipengaruhi oleh beberapa faktor, diantaranya $\mathrm{pH}$, komposisi kimia air limbah (derajat kejenuhan terhadap magnesium, amonium dan fosfat, kehadiran ion lainnya) dan suhu larutan (Khai dan Trang, 2012). Adapun Faktor yang paling berpengaruh pada presipitasi struvite adalah rasio molar $\mathrm{Mg}^{2+}: \mathrm{NH}_{4}^{+}: \mathrm{PO}_{4}{ }^{3-}$ dan $\mathrm{pH}$ (Kumar dan Pal, 2013). Kelebihan yang dimiliki oleh metode ini yaitu terbentuknya kembali senyawa dari $\mathrm{PO}_{4}{ }^{3-}, \mathrm{Mg}^{2+}$, dan $\mathrm{NH}_{4}{ }^{+}$sebagai struvite yang dapat dimanfaatkan sebagai pupuk yang besifat slow-release (Rahman et al., 2014). Studi menggunakan limbah cair agroindustri menunjukkan bahwa struvite dapat menjadi pupuk yang sangat bermanfaat yang mengandung hampir semua makronutrien utama $(\mathrm{N}, \mathrm{P}, \mathrm{Mg}, \mathrm{K})$ dan makronutrien sekunder penting lainnya, seperti $\mathrm{Na}$ dan $\mathrm{Ca}$ (Taddeo et al., 2018).

Penelitian ini bertujuan untuk mengevaluasi efisiensi penyisihan amonium dan polutan penting lainnya dari air limbah tempat pembuangan sampah pada berbagai rasio molar presipitan dan $\mathrm{pH}$ dengan menggunakan studi kasus air lindi dari TPA Galuga, Bogor.

\section{BAHAN DAN METODE}

\section{Alat dan Bahan}

Peralatan yang digunakan dalam penelitian ini adalah serangkaian uji jar test untuk menentukan rasio molar terbaik. Analisis laboratorium mengunakan alat distilasi, turbidity meter, spektofotometer HACH DR/3900, pH meter, dan peralatan gelas lainnya. Bahan utama air lindi diperoleh yang digunakan pada penelitian ini adalah air lindi dari TPA Galuga, Bogor, Jawa Barat. Bahan kimia untuk presipitasi struvite yang digunakan adalah $\mathrm{MgCl}_{2} \cdot 6 \mathrm{H}_{2} \mathrm{O}$ dan $\mathrm{Na}_{2} \mathrm{HPO}_{4} \cdot 2 \mathrm{H}_{2} \mathrm{O}$. Bahan bahan lainnya yang digunakan untuk analisis adalah larutan $\mathrm{NaOH} 3 \mathrm{~N}$ untuk mengontrol $\mathrm{pH}$ larutan, larutan aquades, larutan asam borat $2 \%$, indikator mengsel, larutan digestion reagent, larutan $\mathrm{H}_{2} \mathrm{SO}_{4}$ $0,02 \mathrm{~N}$, larutan $\mathrm{NaOH} 6 \mathrm{~N}$ dan gliserol.

\section{Pengambilan Sampel Dan Karakterisasiawal Air Lindi (leachate)}

Air lindi yang digunakan untuk penelitian ini diambil dari kolam kontrol TPA Galuga menggunakan jirigen 20L. Air lindi yang belum digunakan disimpan dalam penyimpanan dingin (cold storage). Karakterisasi awal air lindi meliputi analisis amonium (SNI 06-6989.30-2005), COD (SNI 6989.73: 2009), TSS (APHA ed. 21 ${ }^{\text {th }} 5220$ C, 2005), nilai kekeruhan (APHA ed. $21^{\text {th }} 2130$ B, 2005) dan warna (APHA ed. $21^{\text {th }} 2120 \mathrm{C}$, 2005). Analisis dilakukan di Laboratorium Teknik dan Manajemen Lingkungan (TML) dan Laboratorium Instrumen Departemen Teknologi Industri Pertanian, Institut Pertanian Bogor.

\section{Proses Presipitasi Struvite}

Air lindi yang sudah berada pada suhu ruang diambil sebanyak $500 \mathrm{~mL}$ dan dimasukkan ke dalam gelas piala $1 \mathrm{~L}$. Bahan kimia yang digunakan sebagai presipitan adalah $\mathrm{MgCl}_{2} \cdot 6 \mathrm{H}_{2} \mathrm{O}$ sebagai sumber $\mathrm{Mg}^{2+}$ dan $\mathrm{Na}_{2} \mathrm{HPO}_{4} \cdot 2 \mathrm{H}_{2} \mathrm{O}$ sebagai sumber $\mathrm{PO}_{4}{ }^{3-}$. Penambahan presipitan tersebut ke dalam air lindi sesuai dengan dengan perkiraan rasio molar. Proses presipitasi dilakukan dalam skala boratorium. 
Bahan kimia yang digunakan adalah $\mathrm{MgCl}_{2} \cdot 6 \mathrm{H}_{2} \mathrm{O}$ dan $\mathrm{Na}_{2} \mathrm{HPO}_{4} .2 \mathrm{H}_{2} \mathrm{O}$. Bahan kimia tersebut direaksikan dengan air lindi pada berbagai variasi rasio molar dan $\mathrm{pH}$.

Nilai $\mathrm{pH}$ diatur pada berbagai $\mathrm{pH} 6,9,8,9$, dan 10 menggunakan penambahan $\mathrm{NaOH} 3 \mathrm{~N}$. Proses presipitasi struvite dilakukan dengan menggunakan alat jar test dengan kecepatan pengadukan $120 \mathrm{rpm}$ selama 15 menit (Gambar 1). Setelah itu, struvite yang terbentuk diendapkan. Proses pengendapan dilakukan selama 45 menit. Cairan supernatan disaring menggunakan kertas saring dan dimasukkan ke dalam botol sampel untuk dianalisis parameter amonium, COD, TSS, kekeruhan, dan warna. Pengukuran parameter polutan tersebut dilakukan dengan menggunakan metode baku sesuai dengan SNI atau APHA ed. 21 ${ }^{\text {th }}$, tahun 2005.

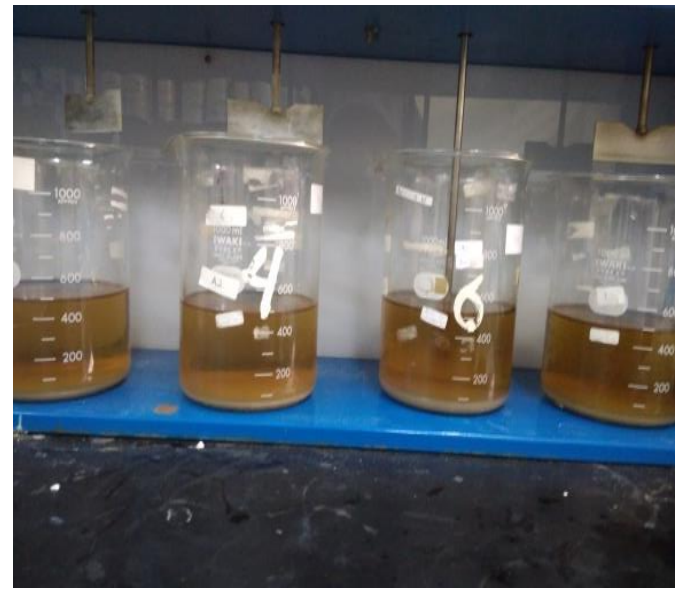

Gambar 1. Peralatan jar test

Tabel 1. Rasio molar $\mathrm{NH}_{4}{ }^{+}: \mathrm{Mg}^{2+}: \mathrm{PO}_{4}{ }^{3-}$ serta jumlah penambahan presipitan $\mathrm{MgCl}_{2} .6 \mathrm{H}_{2} \mathrm{O}$ dan $\mathrm{Na}_{2} \mathrm{HPO}_{4} .2 \mathrm{H}_{2} \mathrm{O}$

\begin{tabular}{|c|c|}
\hline $\begin{array}{c}\text { Rasio Molar } \\
\mathrm{NH}_{4}^{+}: \mathrm{Mg}^{2+}: \mathrm{PO}_{4}^{3-}\end{array}$ & $\begin{array}{c}\text { Massa } \\
\mathrm{MgCl}_{2.6 H_{2}} \mathrm{O}+ \\
\mathrm{Na}_{2} \mathrm{HPO}_{4.2 \mathrm{H}_{2} \mathrm{O}(\mathrm{g} / \mathrm{L})}\end{array}$ \\
\hline $1: 1,3: 1$ & $4,23+3,82$ \\
\hline $1: 1,5: 1$ & $5,27+3,82$ \\
\hline $1: 1,5: 0,8$ & $5,27+3,06$ \\
\hline $1: 1,3: 1,2$ & $4,23+4,58$ \\
\hline
\end{tabular}

Faktor yang dikaji pada penelitian ini adalah rasio molar dan $\mathrm{pH}$. Rasio molar antara $\mathrm{NH}_{4}{ }^{+}$: $\mathrm{Mg}^{2+}$ : $\mathrm{PO}_{4}{ }^{3-}$ bervariasi untuk menentukan rasio molar optimum yang diterapkan dalam pengolahan air lindi untuk memperoleh penyisihan amonium tertinggi. Secara teoritis untuk menghilangkan seluruh konsentrasi amonium, reaksi kimia harus memiliki rasio molar $\mathrm{NH}_{4}^{+}: \mathrm{Mg}^{2+}$ : $\mathrm{PO}_{4}{ }^{3-}$ yang bernilai 1:1:1. Karakterisasi konsentrasi awal amonium diperlukan untuk perhitungan stoikiometri jumlah bahan presipitan yang harus ditambahkan pada air lindi. Rasio molar serta jumlah penambahan presipitan dapat dilihat pada Tabel 1. Presipitasi pada berbagai dosis presipitan tersebut dilakukan pada berbagai nilai $\mathrm{pH}$, yaitu $\mathrm{pH}$ 6,9, $\mathrm{pH} 8, \mathrm{pH} 9$ dan $\mathrm{pH} 10$.

\section{HASIL DAN PEMBAHASAN}

\section{Karakteristik Air Lindi Awal}

Air lindi yang digunakan untuk penelitian ini diambil dari Tempat pengolahan akhir (TPA) Galuga, Kabupaten Bogor. TPA ini telah beroperasi sejak tahun 1992 dengan sistem pengolahan sampah secara open dumping, yaitu sistem pembuangan sampah di lahan tanpa pengolahan lebih lanjut. Pengambilan sampel air lindi dilakukan pada bulan Februari 2018, dimana berdasarkan data BMKG Bogor (2018) rata-rata curah hujan pada di atas 30 mm. Tabel 2 menunjukkan hasil karakterisasi air lindi TPA Galuga.

Tabel 1. Karakterisasi air lindi TPA Galuga

\begin{tabular}{lcc}
\hline Parameter & Satuan & Nilai \\
\hline $\mathrm{pH}$ & - & $7,80 \pm 0,05$ \\
$\mathrm{Suhu}$ & ${ }^{\circ} \mathrm{C}$ & $28,7 \pm 2,0$ \\
$\mathrm{COD}$ & $\mathrm{mg} / \mathrm{L}$ & $485 \pm 0,00$ \\
Warna & $\mathrm{PtCo}$ & $1897 \pm 3,54$ \\
Kekeruhan & $\mathrm{NTU}$ & $95,5 \pm 0.7$ \\
$\mathrm{TSS}$ & $\mathrm{mg} / \mathrm{L}$ & $164 \pm 0.0$ \\
$\mathrm{NH}_{4}{ }^{+}$ & $\mathrm{mg} / \mathrm{L}$ & $389 \pm 0,0$ \\
$\mathrm{Mg}^{2+}$ & $\mathrm{mg} / \mathrm{L}$ & $162 \pm 4,2$ \\
$\mathrm{PO}_{4}{ }^{3-}$ & $\mathrm{mg} / \mathrm{L}$ & $6,40 \pm 0,01$ \\
\hline
\end{tabular}

Pengamatan secara visual, air lindi TPA Galuga berwarna kuning kecokelatan dan berbau cukup menyengat. Air lindi TPA Galuga memiliki pH 7,8 (Tabel 2). Suhu air lindi di TPA Galuga bernilai $28,7^{\circ} \mathrm{C}$ yang mengikuti suhu lingkungan pada saat pengukuran. Dilihat dari parameter amonium dan beberapa parameter limbah cair lainnya hasil karakterisasi air lindi TPA Galuga, bahwa air lindi tersebut mengandung polutan dengan konsentrasi cukup tinggi, sehingga perlu penanganan sebelum air lindi tersebut dibuang ke lingkungan untuk mencegah terjadinya pencemaran lingkungan. Baku mutu air limbah untuk proses pengolahan akhir sampah sesuai Peraturan Menteri Lingkungan Hidup dan Kehutanan No. P.59/2016 adalah pH 6-9, BOD $150 \mathrm{mg} / \mathrm{L}$, COD $300 \mathrm{mg} / \mathrm{L}$, TSS $100 \mathrm{mg} / \mathrm{L}$, N Total $60 \mathrm{mg} / \mathrm{L}$, merkuri $0,005 \mathrm{mg} / \mathrm{L}$, dan kadmium 0,1 $\mathrm{mg} / \mathrm{L}$.

\section{Pengaruh Rasio Molar dan pH terhadap Konsentrasi $\mathrm{NH}_{4}^{+}$ \\ Air lindi yang digunakan memiliki} konsentrasi $\mathrm{NH}_{4}^{+}$awal cukup tinggi, yaitu sebesar 389,4 mg/L. Gambar 2 menunjukkan efisiensi penyisihan amonium pada berbagai rasio molar 
$\left(\mathrm{NH}_{4}{ }^{+}: \mathrm{Mg}^{2+}: \mathrm{PO}_{4}{ }^{3-}\right)$ dan $\mathrm{pH}$. Penyisihan amonium terjadi secara signifikan pada $\mathrm{pH} 9$ dan 10 pada setiap rasio molar yang digunakan. Efisiensi penyisihan $\mathrm{NH}_{4}{ }^{+}$pada berbagai rasio molar dan $\mathrm{pH}$ berkisar antara 53,55\% hingga 82,54\%. Efisiensi penyisihan konsentrasi $\mathrm{NH}_{4}^{+}$tertinggi terjadi pada rasio molar 1:1,3:1,2 dan $\mathrm{pH} 10$ yaitu sebesar $82,54 \%$ dengan konsentrasi akhir $\mathrm{NH}_{4}{ }^{+}$sebesar $67,98 \mathrm{mg} / \mathrm{L}$. Efisiensi penyisihan konsentrasi $\mathrm{NH}_{4}{ }^{+}$ pada rasio molar 1:1,3:1,2 dan $\mathrm{pH} 9$ sebesar $80,51 \%$ dengan konsentrasi $\mathrm{NH}_{4}{ }^{+}$akhir sebesar 75,9 mg/L. Pemilihan rasio molar dan $\mathrm{pH}$ terbaik dilakukan berdasarkan efisiensi penurunan konsentrasi $\mathrm{NH}_{4}{ }^{+}$ tertinggi. Dengan tingkat eliminasi $\mathrm{NH}_{4}{ }^{+}$tertinggi, diharapkan perolehan struvite lebih tinggi dan kualitas air lindi hasil olahan lebih baik. Rasio molar terbaik yang terpilih adalah 1:1,3:1,2 dan $\mathrm{pH} 9$.

Menurut Fitriana (2016), semakin banyak penambahan ion $\mathrm{Mg}^{2+}$ dan $\mathrm{pH}$ semakin basa maka akan menyebabkan terbentuknya bobierrite $\left(\mathrm{Mg}_{3}\left(\mathrm{PO}_{4}\right)_{2} \bullet 8 \mathrm{H}_{2} \mathrm{O}\right)$, sehingga struvite yang dihasilkan tidak murni. Selain itu, jika dilihat dari segi biaya harga bahan presipitan $\mathrm{MgCl}_{2} \cdot 6 \mathrm{H}_{2} \mathrm{O}$ sebagai sumber $\mathrm{Mg}^{2+}$ dibanding dengan $\mathrm{Na}_{2} \mathrm{HPO}_{4} \cdot 2 \mathrm{H}_{2} \mathrm{O}$ sebagai sumber $\mathrm{PO}_{4}{ }^{3-}$. Oleh sebab itu, penggunaan bahan prespitan harus diminimasi. Nilai $\mathrm{pH}$ yang dipilih didasarkan atas baku mutu air lindi, yaitu berkisar antara 6-9. Penggunaan $\mathrm{NaOH}$ dan sumber asam untuk pengaturan $\mathrm{pH}$ juga berhubungan dengan biaya yang digunakan dalam proses pengolahan. Mekanisme penyisihan amonium mengikuti persamaan (1), dimana kesetimbangan antara reaktan $\left(\mathrm{NH}_{4}{ }^{+}: \mathrm{Mg}^{2+}: \mathrm{PO}_{4}{ }^{3-}\right)$ dan produk (struvite) dipengaruhi oleh berbagai faktor, misalnya $\mathrm{pH}$, suhu dan keberadaan ion lainnya. Sesuai dengan hasil penelitian Turker dan Elen (2010), pengendapan struvite terjadi pada pada $\mathrm{pH}$ netral dan lebih tinggi.

Hasil uji lanjut Duncan terhadap pengaruh $\mathrm{pH}$ (data tidak disajikan) menunjukkan bahwa eliminasi amonium pada keempat taraf $\mathrm{pH}$ tersebut berbeda nyata satu dengan lainnya. Efisiensi penyisihan konsentrasi amonium pada $\mathrm{pH} 10$ lebih besar dibandingkan perlakuan $\mathrm{pH}$ lainnya. Hasil uji lanjut Duncan terhadap pengaruh rasio molar $\mathrm{NH}_{4}{ }^{+}$: $\mathrm{Mg}^{2+}$ : $\mathrm{PO}_{4}{ }^{3-}$ menunjukkan bahwa keempat taraf rasio molar yang digunakan terdapat rasio molar yang berbeda nyata dan terdapat 2 perlakuan rasio molar yang tidak berbeda nyata yaitu antara rasio molar 1:1,5:1 dan 1:1,5:0,8. Efisiensi penyisihan konsentrasi tertinggi pada rasio molar 1:1,3:1,2. Hasil uji lanjut Duncan terhadap interaksi $\mathrm{pH}$ dan rasio molar menunjukkan bahwa perlakuan 1:1,3:1,2 dan $\mathrm{pH} 10$ memiliki efisiensi tertinggi. Menurut persamaan reaksi (1), $\mathrm{Mg}^{2+}, \mathrm{NH}_{4}^{+}$, dan $\mathrm{PO}_{4}{ }^{3-}$ diperlukan dalam jumlah molar yang sama untuk membentuk $\mathrm{MgNH}_{4} \mathrm{PO}_{4} \cdot 6 \mathrm{H} 2 \mathrm{O}$. Namun, spesies kimia lain yang ada di dalam larutan dapat membentuk senyawa dengan $\mathrm{Mg}^{2+}, \mathrm{NH}_{4}^{+}$, dan/atau $\mathrm{PO}_{4}{ }^{3-}$. Oleh karena itu, untuk mengendapkan pengendapan massa $\mathrm{NH}_{4}^{+}$maksimum diperlukan tambahan $\mathrm{Mg}^{2+}$ dan/atau $\mathrm{PO}_{4}{ }^{3-}$ (Turker dan Elen, 2010).

\section{Pengaruh Rasio Molar dan pH terhadap COD}

Air lindi yang digunakan memiliki konsentrasi COD sebesar 484,8 mg/L. Gambar 3 menunjukkan efisiensi penyisihan COD pada berbagai rasio molar dan $\mathrm{pH}$ dengan presipitasi struvite. Efisiensi penyisihan COD berkisar dalam selang mulai dari 17,5\% hingga 80,83\%. Efisiensi penyisihan tertinggi diperoleh pada rasio molar 1:1,5:0,8 dan $\mathrm{pH} 10$, yaitu sebesar $80,83 \%$ dengan konsentrasi akhir COD sebesar 92,92 mg/L. Efisiensi penyisihan COD pada rasio molar 1:1,3:1,2 dan pH 9 sebesar 46,67\% dengan konsentrasi akhir COD sebesar 258,56 mg/L. Penyisihan pada rasio molar 1:1,3:1,2 dan pH 10 menunjukkan hasil yang memenuhi baku mutu. Menurut Kemen LHK No P.59/2016, batas maksimum COD pada air lindi yang boleh dibuang ke lingkungan sebesar 300 $\mathrm{mg} / \mathrm{L}$.

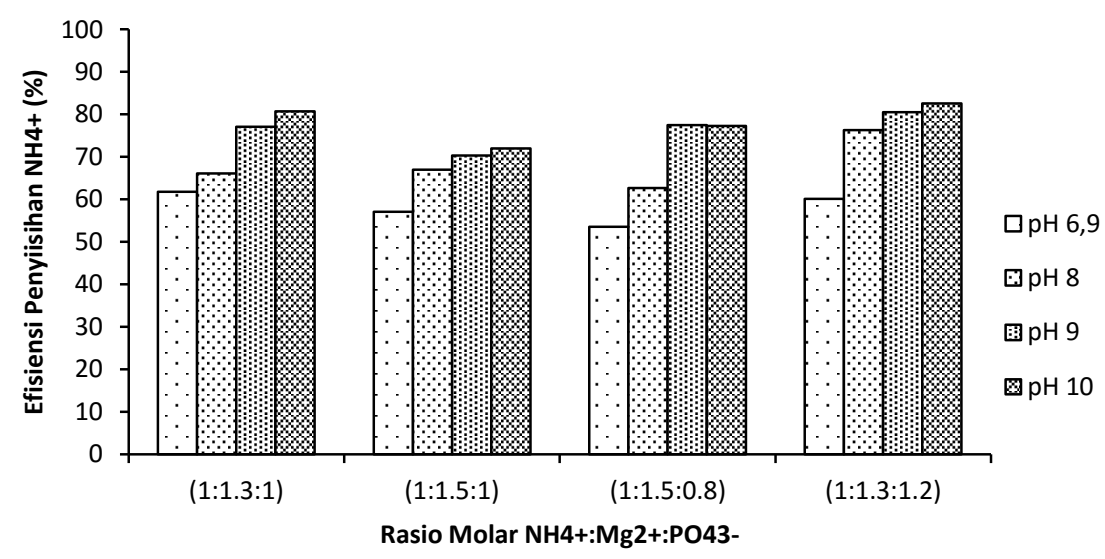

Gambar 2. Efisiensi penyisihan $\mathrm{NH}_{4}{ }^{+}$pada berbagai rasio molar dan $\mathrm{pH}$ 


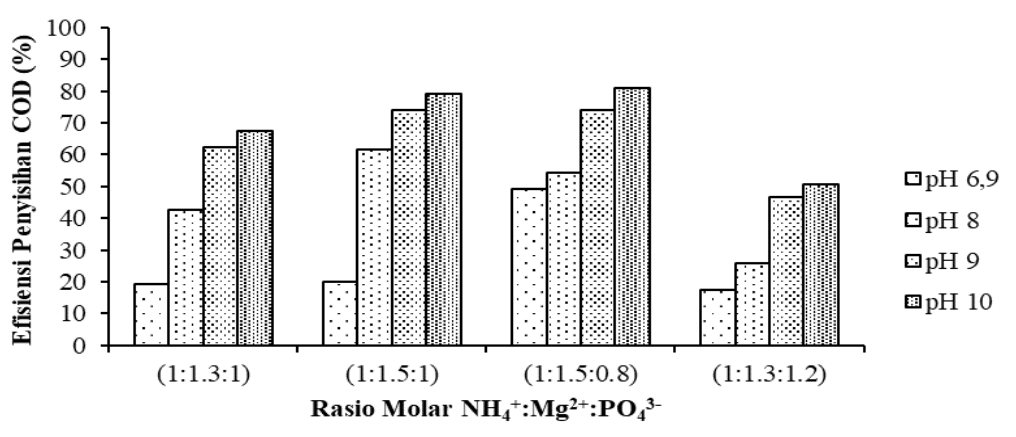

Gambar 3. Efisiensi penyisihan COD pada berbagai rasio molar dan $\mathrm{pH}$

Hasil analisis ragam menunjukkan bahwa konsentrasi COD dipengaruhi oleh rasio molar $\left(\mathrm{NH}_{4}{ }^{+}: \mathrm{Mg}^{2+}: \mathrm{PO}_{4}{ }^{3-}\right), \mathrm{pH}$, dan interaksi antara kedua faktor tersebut. Lebih lanjut, hasil uji Duncan terhadap pengaruh $\mathrm{pH}$ menunjukkan bahwa keempat taraf $\mathrm{pH}$ tersebut memberikan hasil yang berbeda nyata satu dengan lainnya. Efisiensi penyisihan konsentrasi COD pada supernatan $\mathrm{pH} 10$ lebih besar dibandingkan perlakuan $\mathrm{pH}$ lainnya. Hasil uji Duncan terhadap pengaruh rasio molar $\mathrm{NH}_{4}{ }^{+}: \mathrm{Mg}^{2+}$ : $\mathrm{PO}_{4}{ }^{3-}$ menunjukkan bahwa keempat taraf rasio molar yang digunakan memberikan hasil berbeda nyata satu sama lain.

Efisiensi penyisihan konsentrasi COD tertinggi pada rasio molar 1:1,3:1,2. Hasil uji lanjut Duncan terhadap interaksi $\mathrm{pH}$ dan rasio molar menunjukkan bahwa perlakuan 1:1,3:1,2 dan $\mathrm{pH} 10$ memiliki efisiensi tertinggi. Penyisihan bahan organik (COD) merupakan akibat tidak langsung dari proses presipitasi struvite, dimana bahan-bahan organik terlarut atau tersuspensi dapat teradsorpsi pada partikel-partikel struvite atau partikel lainnya yang terbentuk dan terbawa mengendap. Penurunan COD juga dapat akibat dari penambahan ion $\mathrm{Mg}^{2+}$. Ion $\mathrm{Mg}^{2+}$ sering digunakan sebagai flokulan untuk mengurangi kandungan partikel organik di dalam limbah cair (Li et al., 2012). Karena dosis presipitan dan $\mathrm{pH}$ mempengaruhi proses pembentukan struvite, maka rasio molar dan nilai $\mathrm{pH}$ juga mempengaruhi tingkat eliminasi COD, sebagaimana ditunjukkan pada Gambar 3.

\section{Pengaruh Rasio Molar dan pH terhadap Padatan Tersuspensi Total}

Air lindi yang digunakan memiliki kandungan TSS awal sebesar $164 \mathrm{mg} / \mathrm{L}$. Gambar 4 menunjukkan efisiensi penyisihan kandungan TSS pada berbagai rasio molar dan nilai $\mathrm{pH}$. Efisiensi penyisihan kandungan TSS tertinggi terjadi pada rasio molar 1:1,3:1,2 dan $\mathrm{pH} 10$ yaitu sebesar 96,04\% dengan kandungan TSS akhir sebesar 6,5 $\mathrm{mg} / \mathrm{L}$. Hasil tersebut mirip dengan hasil efisiensi pada rasio molar 1:1,3:1,2 dan $\mathrm{pH}$ 9. Kadar TSS ini telah sesuai dengan baku mutu TSS menurut KemenLHK No P.59/2016, dimana batas maksimum TSS pada air lindi yang diijinkan dibuang ke lingkungan sebesar $100 \mathrm{mg} / \mathrm{L}$. Proses presipitasi dapat mengendapkan struvite dan padatan lainnya, sehingga proses ini menyebabkan menurunnya kandungan TSS air lindi. Efektivitas penurunan kandungan padatan tersuspensi dipengaruhi oleh beberapa faktor, antara lain kecepatan dan pengadukan dan waktu pengendapan. Penyisihan TSS merupakan akibat tidak langsung dari proses presipitasi struvite, dimana TSS dapat teradsorpsi pada partikel-partikel struvite atau partikel lainnya yang terbentuk dan terbawa mengendap. Karena dosis presipitan dan $\mathrm{pH}$ mempengaruhi proses pembentukan dan pengendapan struvite, maka dosis presipitan dan nilai $\mathrm{pH}$ juga mempengaruhi tingkat eliminasi TSS.

Hasil analisis ragam menunjukkan bahwa kandungan TSS dipengaruhi oleh rasio molar $\left(\mathrm{NH}_{4}{ }^{+}\right.$ $\left.: \mathrm{Mg}^{2+}: \mathrm{PO}_{4}^{3-}\right), \mathrm{pH}$, dan interaksi antara kedua faktor tersebut. Lebih lanjut, hasil uji Duncan terhadap pengaruh $\mathrm{pH}$ menunjukkan bahwa keempat taraf $\mathrm{pH}$ tersebut berbeda nyata satu dengan lainnya. Efisiensi penyisihan kandungan TSS pada $\mathrm{pH} 10$ lebih besar dibandingkan perlakuan $\mathrm{pH}$ lainnya. Hasil uji lanjut Duncan terhadap rasio molar $\mathrm{NH}_{4}^{+}: \mathrm{Mg}^{2+}: \mathrm{PO}_{4}^{3-}$ menunjukkan bahwa keempat rasio molar yang digunakan berbeda nyata satu sama lain. Efisiensi penyisihan TSS tertinggi pada rasio molar 1:1,3:1,2.

Hasil uji lanjut Duncan terhadap interaksi $\mathrm{pH}$ dan rasio molar menunjukkan bahwa perlakuan 1:1,3:1,2 dan $\mathrm{pH} 10$ menghasilkan efisiensi penyisihan TSS tertinggi. Perbedaan efisiensi tersebut terkait dengan perbandingan masing-masing reaktan secara stokiometris, serta pengaruh $\mathrm{pH}$ pada kesetimbangan reaksi dan kelarutan struvite, dimana kelarutan struvite menurun dengan meningkatnya nilai $\mathrm{pH}$. Lebih lanjut, tingkat pengendapan struvite berpengaruh pada tingkat eliminasi parameter lainnya, seperti TSS. Semakin tinggi tingkat eliminasi amonium, makin tinggi tingkat eliminasi parameter TSS.

\section{Pengaruh Rasio Molar dan pH terhadap Kekeruhan}

Air lindi yang digunakan dalam penelitian memiliki nilai kekeruhan awal sebesar 95,5 NTU. Gambar 5 menunjukkan efisiensi penyisihan nilai 
kekeruhan pada berbagai rasio molar dan $\mathrm{pH}$. Penyisihan kekeruhan merupakan akibat langsung dari proses pengendapan TSS, dimana kekeruhan ditentukan oleh TSS. TSS berukuran relatif besar dapat mengendap secara langsung, sedangkan partikel berukuran relatif kecil dapat teradsorpsi pada partikel-partikel struvite terbentuk dan terbawa mengendap. Karena dosis presipitan dan $\mathrm{pH}$ mempengaruhi proses pembentukan struvite, maka faktor ini juga mempengaruhi tingkat eliminasi TSS. Lebih lanjut, penurunan TSS ini menurunkan tingkat penyisihan kekeruhan.

Efisiensi penyisihan kekeruhan pada berbagai rasio molar dan $\mathrm{pH}$ menunjukkan berkisar antara $75,95 \%$ hingga $99,1 \%$. Efisiensi penyisihan kekeruhan tertinggi diperoleh pada rasio molar 1:1,5:0,8 dan $\mathrm{pH} 10$ yaitu sebesar 99,1\% dengan nilai kekeruhan akhir sebesar 0,86 NTU. Efisiensi penyisihan kekeruhan pada rasio molar 1:1,3:1,2 dan pH 9 sebesar 96,79\% dengan nilai kekeruhan akhir sebesar 3,06 NTU. Penurunan tertinggi terjadi karena adanya penambahan $\mathrm{Mg}^{2+}$ lebih banyak, maka efisiensi penyisihan kekeruhan semakin tinggi.
Hasil analisis ragam menunjukkan bahwa nilai kekeruhan dipengaruhi oleh rasio molar $\mathrm{NH}_{4}{ }^{+}$: $\mathrm{Mg}^{2+}$ : $\mathrm{PO}_{4}{ }^{3-}, \mathrm{pH}$, dan interaksi antara kedua faktor tersebut. Hasil uji lanjut Duncan terhadap $\mathrm{pH}$ menunjukkan bahwa keempat $\mathrm{pH}$ tersebut berbeda nyata satu dengan lainnya. Efisiensi penyisihan nilai warna pada supernatan $\mathrm{pH} 10$ lebih besar dibandingkan perlakuan $\mathrm{pH}$ lainnya. Hasil uji lanjut Duncan terhadap rasio molar $\mathrm{NH}_{4}{ }^{+}: \mathrm{Mg}^{2+}: \mathrm{PO}_{4}{ }^{3-}$ menunjukkan bahwa keempat rasio molar yang digunakan berbeda nyata satu sama lain. Efisiensi penyisihan nilai warna tertinggi pada rasio molar 1:1,5:1. Hasil uji lanjut Duncan terhadap interaksi $\mathrm{pH}$ dan rasio molar menunjukkan bahwa perlakuan 1:1,5:0,8 dan $\mathrm{pH} 10$ memiliki efisiensi tertinggi. Perbedaan efisiensi kekeruhan tersebut terkait dengan perbandingan masing-masing reaktan secara stokiometris, serta pengaruh $\mathrm{pH}$ pada kelarutan struvite. Kelarutan struvite menurun dengan meningkatnya nilai $\mathrm{pH}$ dan tingkat pengendapan struvite berpengaruh pada tingkat eliminasi parameter lainnya, termasuk kekeruhan

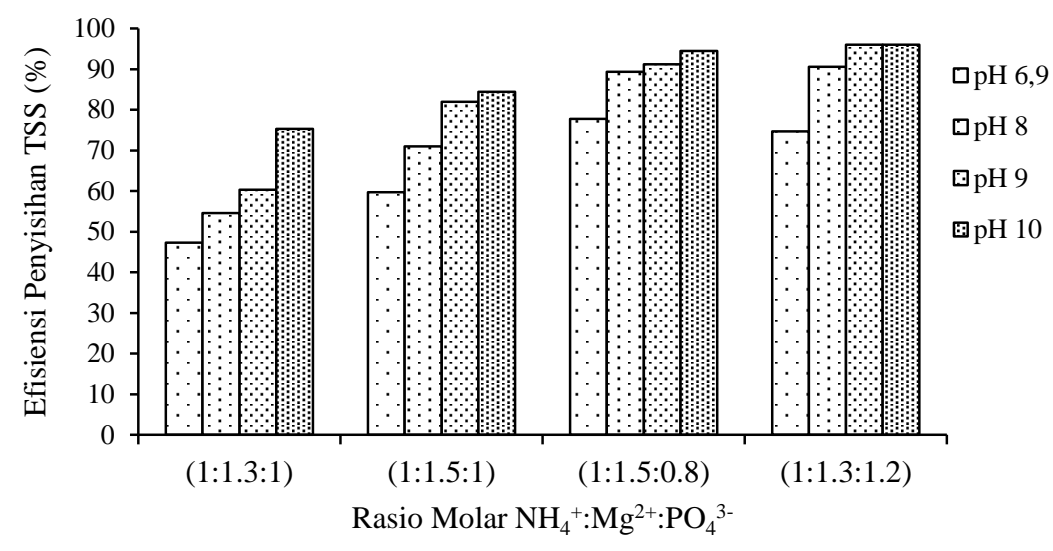

Gambar 4. Efisiensi penyisihan kandungan TSS pada berbagai rasio molar dan $\mathrm{pH}$

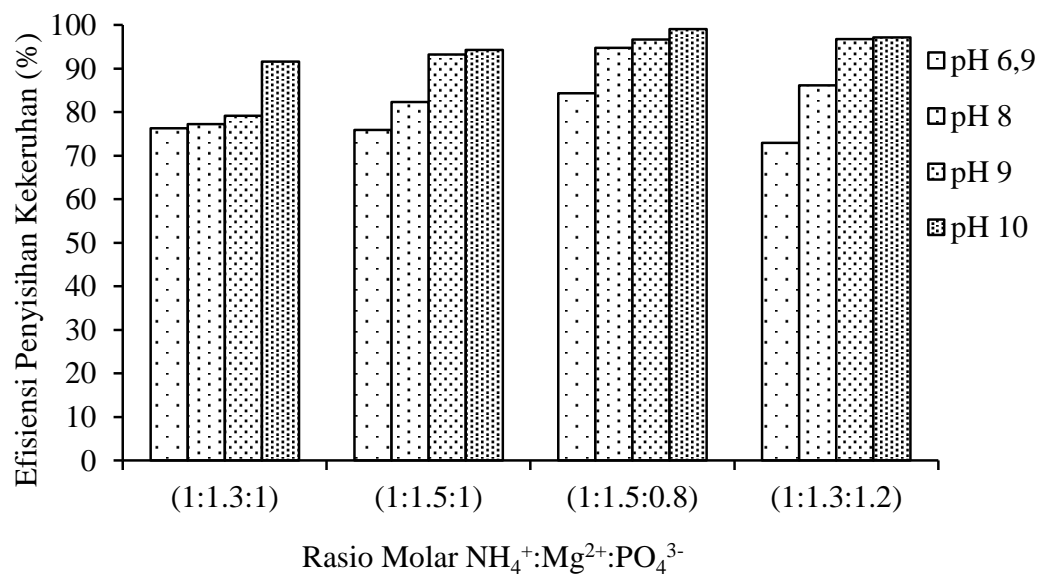

Gambar 5. Efisiensi penyisihan nilai kekeruhan pada berbagai rasio molar dan $\mathrm{pH}$ 
Pengaruh Rasio Molar dan pH terhadapWarna

Air lindi yang digunakan memiliki nilai warna awal sebesar 1897,5 PtCo. Gambar 6 menunjukkan efisiensi penyisihan warna pada berbagai rasio molar dan $\mathrm{pH}$. Penyisihan warna dapat akibat langsung atau tidak langsung dari proses presipitasi struvite, dimana warna dipengaruhi oleh bahan terlarut. Bahan terlarut kemungkinan dapat terkoagulasi atau teradsorpsi pada partikel-partikel struvite yang terbentuk dan terbawa mengendap. Karena dosis presipitan dan $\mathrm{pH}$ mempengaruhi proses pembentukan struvite, maka faktor ini juga mempengaruhi tingkat eliminasi polutan lainnya, termasuk warna. Semakin tinggi eliminasi amonium, semakin tinggi pula tingkat eliminasi warna.

Parameter TSS, kekeruhan dan warna memiliki hubungan yang berkaitan satu sama lain. Parameter nilai warna menunjukkan hasil yang berbanding lurus bahan terlarut, dan berkaitan dengan parameter TSS dan kekeruhan. Efisiensi penyisihan nilai warna tertinggi terjadi pada rasio molar 1:1,3:1,2 dan $\mathrm{pH} 10$ yaitu sebesar 88,14\% dengan nilai warna akhir sebesar 225 PtCo. Berdasarkan pengamatan secara visual, warna air lindi setelah proses pengolahan pada $\mathrm{pH}$ 6,9-9 memiliki warna kuning dan lebih jernih jika dibandingkan dengan warna air lindi sebelum diproses. Air lindi sebelum diproses memiliki warna kecokelatan. Nilai warna dipengaruhi oleh adanya bahan-bahan terlarut bermuatan negatif, dan penabahan ion positif akan menurunkan warna pada air lindi, misalnya $\mathrm{Mg}^{2+}$.

Hasil analisis ragam menunjukkan bahwa nilai warna dipengaruhi oleh rasio molar $\left(\mathrm{NH}_{4}{ }^{+}\right.$: $\left.\mathrm{Mg}^{2+}: \mathrm{PO}_{4}{ }^{3-}\right), \mathrm{pH}$, dan interaksi antara kedua faktor tersebut. Hasil uji lanjut Duncan terhadap pengaruh $\mathrm{pH}$ menunjukkan bahwa keempat taraf $\mathrm{pH}$ tersebut memberikan hasil yang berbeda nyata satu dengan lainnya. Efisiensi penyisihan nilai warna pada supernatan $\mathrm{pH} \quad 10$ lebih tinggi dibandingkan perlakuan $\mathrm{pH}$ lainnya. Hasil uji lanjut Duncan terhadap rasio molar $\mathrm{NH}_{4}{ }^{+}: \mathrm{Mg}^{2+}: \mathrm{PO}_{4}{ }^{3-}$ menunjukkan bahwa keempat taraf rasio molar yang digunakan memberikan hasil yang berbeda nyata satu sama lain. Efisiensi penyisihan nilai warna tertinggi terjadi pada rasio molar 1:1,3:1,2. Hasil uji lanjut Duncan terhadap interaksi $\mathrm{pH}$ dan rasio molar menunjukkan bahwa perlakuan 1:1,3:1,2 dan $\mathrm{pH} 10$ memiliki efisiensi tertinggi dalam hal penyisihan warna.

\section{KESIMPULAN DAN SARAN}

\section{Kesimpulan}

Proses presipitasi struvite dengan menggunakan $\mathrm{MgCl}_{2} \cdot 6 \mathrm{H}_{2} \mathrm{O}$ dan $\mathrm{Na}_{2} \mathrm{HPO}_{4} \cdot 2 \mathrm{H}_{2} \mathrm{O}$ sebagai bahan presipitan amonium dipengaruhi oleh rasio molar presipitan dan nilai $\mathrm{pH}$. Berasarkan efisiensi penyisihan ammonium, COD, TSS, kekeruhan dan warna, rasio molar $\mathrm{NH}_{4}{ }^{+}: \mathrm{Mg}^{2+}$ : $\mathrm{PO}_{4}{ }^{3-}=1: 1,3: 1,2$ dan $\mathrm{pH} 9$ dapat memberikan hasil terbaik. Proses pesipitasi pada rasio molar dan $\mathrm{pH}$ tersebut menghasilkan penyisihan amonium sebesar $80,51 \%$ dan konsentrasi $\mathrm{NH}_{4}{ }^{+}$akhir sebesar 75,9 $\mathrm{mg} / \mathrm{L}$. Pada kondisi tersebut, diperoleh penyisihan COD sebesar 46,67\%, TSS 96,04\%, kekeruhan $86,1 \%$, dan warna sebesar $86,43 \%$. Nilai $\mathrm{pH}$ berpengaruh pada tingkat penyisihan polutan air lindi, dimana semakin tinggi nilai $\mathrm{pH}$ semakin tinggi pula tingkat penyisihan polutan yang diamati. Penambahan presipitan tidak hanya menurunkan konsentrasi amonium, tetapi juga polutan lainnya seperti COD, TSS, kekeruhan dan warna. Secara umum, semakin tinggi tingkat eliminasi amonium, makin tinggi tingkat eliminasi parameter lainnya, seperti COD, TSS, kekeruhan dan warna.

\section{Saran}

Karakterisasi dan analisa kelayakan penggunaan struvite yang diperoleh sebagai sumber pupuk perlu dikaji lebih lanjut pada skala yang lebih besar.

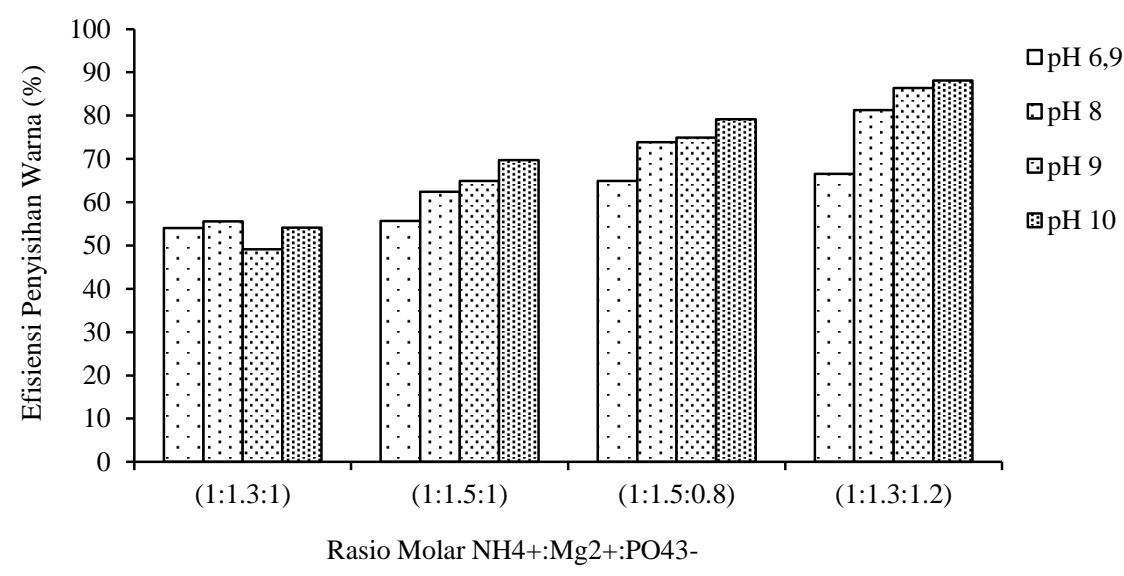

Gambar 6. Nilai warna pada berbagai rasio molar dan $\mathrm{pH}$ 


\section{UCAPAN TERIMA KASIH}

Penilitian ini didukung secara finalsial oleh Direktorat Riset dan Pengabdian Kepada Masyarakat, Direktorat Jenderal Penguatan Riset dan Pengembangan, Kementerian Riset, Teknologi, dan Pendidikan Tinggi melalui Skema Penelitian Berbasis Kompetensi (PBK) Tahun 2018. Untuk itu peneliti menyampaikan terima kasih.

\section{DAFTAR PUSTAKA}

[APHA] America Public Health Association. 2012. Standard Methods for the Examination of Water and Wastewater. $21^{\text {th }} \mathrm{Ed}$. Washington.

[BMKG] Badan Meterologi Klimatologi dan Geofisika. Curah Hujan Februari 2018[internet].www.bmkg.go.id/puncakmusim-hujan-berlangsunghingga-maret/ [diakses 11 Juli 2018].

Anglada A, Urtiaga A, Ortiz I, Mantzavinos D, Diamadopoulos. 2011. Treatment of municipal landfill leachate by catalytic wet air oxidation : assessment of the role of operating parameters by factorial design. Journal Waste Manag. 31 : 2833-1840.

Chou YC, Lo SL, Kuo J, Yeh CJ. 2013. Derivative mechanisms of organic acids in microwave oxidation of landfill leachate. Journal Hazard Mater. (254-255) : 293-300.

Fitriana AR dan Warmadewanthi IDAA. 2016. Penurunan kadar amonium dan fosfat pada limbah cair industri pupuk. Jurnal Teknik ITS. 5(2) : 2337-3539.

Huang H, Xiao D, Zhang Q, Ding L. 2014. Removal of ammonia from landfill leachate by struvite precipitation with the use of lowcost phosphate and magnesium sources. Journal Environ Manag. 145 : 191-198.

Khai NM dan Trang HT. 2012. Chemical precipitation of ammonia and phosphate from nam son landfill leachate Hanoi. Iranica Journal Energy and Environment. 3: 32-36.

Kim D, Kim J, Ryu HD, Lee S. 2009. Effect of mixing on spontaneous struvite precipitation from semiconductor wastewater. Journal Bioresource Techn. 100(1): 74-78.

Kumar R dan Pal P. 2013. Turning hazardous waste into value-added product: production and characterization of struvite from ammoniacal waste with new approaches. Journal Cleaner Production. 43: 59-70.

Kochany J dan Kochany EL. 2009. Utilization of landfill parameters for pretreatment by feton recation and struvite precipitation. Journal Hazard Mater.166: 248-254.

Li ZX, Ren XG, Zuo J, Liu YF, Duan EH, Yang JL, Chen P, Wang YJ. 2012. Struvite precipitation for ammonia nitrogen removal in 7-aminocephalos acid wastewater. Molecules. 17: 2126-2139.

Menteri Lingkungan Hidup dan Kehutanan. 2016. Peraturan Menteri Lingkungan Hidup dan Kehutanan No P.59/2016 tentang Baku Mutu Lindi bagi Usaha dan/atau Kegiatan Tempat Pemrosesan Sampah.

Rahman MM, Salleh MAM, Rashid U, Ahsan A, Hossain MM, Ra CS. 2014. Production of slow release crystal fertilizer from wastewaters through struvite crystallization. Arabian Journal Chemistry. 7: 139-155.

Sanitasi Kota Bogor. 2015. Laporan akhir penyusunan layanan persampahan Kota Bogor Tahun 2014 [internet]. http://sanitasi.kotabogor.go.id/ [diakses pada 10 Juli 2018].

Stegmann R, Heyer KU, dan Cossu R. 2005. Leachate Treatment. Proceedings Sardinia 2005, Tenth International Waste Management and Landfill Symposium S. Margherita di Pula, Cagliari, Italy; 3 - 7 October 2005.

Taddeo R, Honkanen M, Kolppo K, Lepisto R. 2018. Nutrient management via struvite precipitation and recovery from various agroindustrial wastewaters: Process feasibility and struvite quality. Journal Env Manag. 212: 433-439.

Turker M dan Elen IC. 2010. Chemical equilibrium model of struvite precipitation from anaerobic digester effluents. Turkish Journal Eng Env Sci. 34, 39 - 48.

Zhang T, Ding L, Ren H, Xiong X. 2009. Ammonium nitrogen removal from coking wastewater by chemical precipitation recycle technology. Journal Water Res. 43: 52095215. 